\title{
Dissolved inorganic carbon export from carbonate and silicate catchments estimated from carbonate chemistry and $\delta^{13} \mathrm{C}_{\text {DIC }}$
}

\author{
W. J. Shin ${ }^{1,2}$, G. S. Chung ${ }^{1}$, D. Lee ${ }^{2}$, and K. S. Lee ${ }^{2,3}$ \\ ${ }^{1}$ Department of Geology and Earth Environmental Sciences, Chungnam National University, \\ Daejeon, 305-764, Republic of Korea \\ ${ }^{2}$ Division of Earth and Environmental Science, Korea Basic Science Institute, Ochang, 363-883, Republic of Korea \\ ${ }^{3}$ Graduate School of Analytical Science and Technology, Chungnam National University, \\ Daejeon, 305-764, Republic of Korea
}

Received: 31 December 2010 - Published in Hydrol. Earth Syst. Sci. Discuss.: 9 February 2011

Revised: 9 August 2011 - Accepted: 10 August 2011 - Published: 16 August 2011

\begin{abstract}
This work presents a study of the dissolved inorganic carbon (DIC) exchange associated with groundwater discharge and stream flow from two upstream catchments with distinct basement lithologies (silicate vs. carbonate). The effects of catchment lithology were evident in the spring waters showing lower $\delta^{13} \mathrm{C}_{\text {DIC }}$ and alkalinity $\left(-16.2 \pm 2.7 \%\right.$ and $0.09 \pm 0.03 \mathrm{meq}^{-1}$, respectively) in the silicate and higher values $(-9.7 \pm 1.5 \%$ and $2.0 \pm 0.2 \mathrm{meq}^{-1}$ ) in the carbonate catchment. The streams exhibited relatively high $\delta^{13} \mathrm{C}_{\mathrm{DIC}},-6.9 \pm 1.6 \%$ and $-7.8 \pm 1.5 \%$, in silicate and carbonate catchments, respectively, indicating $\mathrm{CO}_{2}$ degassing during groundwater discharge and stream flow. The catchment lithology affected the pattern of DIC export. The $\mathrm{CO}_{2}$ degassing from stream and groundwater could be responsible for $8-55 \%$ of the total DIC export in the silicate catchment, whereas the proportion is comparatively low (0.4-5.6\%) in the carbonate catchment. Therefore, the dynamic carbon exchange occurring at headwater regions and its possible variability with catchment lithology need to be examined for a more reliable carbon budget in river systems.
\end{abstract}

\section{Introduction}

The current increase of atmospheric carbon dioxide, a greenhouse gas, and associated climate changes necessitate a more in-depth understanding of the global carbon cycle (Friedlingstein et al., 2003; Govindasamy et al., 2005). Rivers play

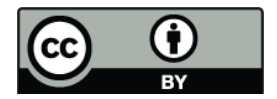

Correspondence to: $\mathrm{K}$. S. Lee (kslee@kbsi.re.kr) an important role in global carbon cycling by transporting carbon from terrestrial to marine realms. The global flux of carbon transported by rivers in the form of dissolved inorganic carbon (DIC) is estimated to be $0.43 \times 10^{15} \mathrm{gC} \mathrm{yr}^{-1}$, representing $\sim 50 \%$ of the total carbon flux (Meybeck, 1987; Cole et al., 2007). Moreover, the evasion of $\mathrm{CO}_{2}$ from rivers during DIC transport is an important component of the atmospheric $\mathrm{CO}_{2}$ budget (Richey et al., 2002). Thus, considerable effort has been directed toward quantifying both vertical (evasion of $\mathrm{CO}_{2}$ ) and lateral (discharge) exports of DIC via rivers (Dubois et al., 2010).

In upstream regions (e.g. headwater catchments) where the stream flow is mainly due to groundwater discharge, groundwater acts as a conduit of subsurface DIC transport across the interface between terrestrial (e.g. soils) and aquatic reservoirs (e.g. streams). The onset of carbon exchange at the headwater regions is characterized by enhanced $\mathrm{CO}_{2}$ evasion due to strong $\mathrm{CO}_{2}$ over-saturation of the groundwater. Because the effect of groundwater DIC is transient and is only observed near the immediate source at the first order stream, carbon exchange at this interface has been largely unexplored (Johnson et al., 2008; Öquist et al., 2009). Therefore, a more quantitative understanding of carbon exchange in headwater systems is essential to derive a reliable carbon budget of river systems.

An isotope tracer, $\delta^{13} \mathrm{C}_{\mathrm{DIC}}$, is especially useful because it reveals reaction pathways and transport processes that may otherwise be difficult to discern with normative carbonate systems (Tan and Edmond, 1993; Taylor and Fox, 1996; Yang et al., 1996). The DIC in river water originates from several sources, including influx of soil $\mathrm{CO}_{2}$ via groundwater, $\mathrm{CO}_{2}$ exchange with the atmosphere, in-river respiration, and dissolution of carbonate rocks. About $67 \%$ of the DIC

Published by Copernicus Publications on behalf of the European Geosciences Union. 
in the world's rivers is known to originate from soil $\mathrm{CO}_{2}$ (Meybeck, 1987; Ludwig et al., 1997). Based on simple stoichiometric considerations, the proportion of soil $\mathrm{CO}_{2}$ in rivers ranges from $\sim 50 \%$ in carbonate catchments (another $50 \%$ is from the carbonate minerals) to $\sim 100 \%$ in silicate catchments (e.g. Spence and Telmer, 2005). In upstream regions where groundwater contributes largely to stream flow, the input of groundwater containing DIC from soil $\mathrm{CO}_{2}$ lowers the ${ }^{13} \mathrm{C} /{ }^{12} \mathrm{C}$ ratio of DIC in river water because soil $\mathrm{CO}_{2}$ is largely derived from the microbial degradation of soil organic matter (Amiotte-Suchet et al., 1999; Finlay, 2003). In contrast, atmospheric exchange and dissolution of carbonate minerals increase the ${ }^{13} \mathrm{C} /{ }^{12} \mathrm{C}$ ratio of DIC because these sources are enriched in ${ }^{13} \mathrm{C}$ relative to ${ }^{12} \mathrm{C}$ (Amiotte-Suchet et al., 1999). In addition to the strong over-saturation with $\mathrm{CO}_{2}$ in groundwater components, stream water in upstream regions may also be more turbulent, causing rapid degassing of $\mathrm{CO}_{2}$ into the atmosphere and remarkable ${ }^{13} \mathrm{C}$ enrichment in DIC (Doctor et al., 2008).

The uppermost tributaries of the South Han River (SHR), South Korea, provide an ideal hydro-geological setting to investigate the effect of catchment lithology on $\delta^{13} \mathrm{C}_{\mathrm{DIC}}$ and carbonate chemistry because they drain catchments with contrasting bedrock lithologies: silicate vs. carbonate. Moreover, their drainage system that consists of the first to fifth order streams provides an adequate condition for studies on carbon exchanges from the headwater regions to the main channels. In this study, the stable carbon isotopic composition of DIC and carbonate chemistry were determined from springs and streams draining upstream catchments with silicate and carbonate basements. The objectives were to (1) determine factors controlling carbonate chemistry and $\delta^{13} \mathrm{C}_{\mathrm{DIC}}$ in catchments with different lithologies and (2) quantify lateral and vertical transport of DIC at the studied catchments and their possible variation with the catchment lithology.

\section{Materials and methods}

\subsection{Description of the study sites}

The study sites were two upstream tributaries of the SHR in the middle part of the Korean peninsula (Fig. 1). Both catchments were located at the headwater regions of the SHR basin. The Odae drains a basin $\left(452 \mathrm{~km}^{2}\right)$ dominated exclusively by silicate rocks, consisting of Precambrian metamorphic crystalline rocks, Permian to Triassic sandstone and shale, and Jurassic to Cretaceous granite. In contrast, the Jijang drains a basin $\left(225 \mathrm{~km}^{2}\right)$ dominated by CambroOrdovician carbonate rocks with some sandstone at its upper reach (Kim et al., 2001). The lower reach of the carbonate catchment consists of Ordovician limestone and both spring and stream water samples were collected from the same rock formation. The sedimentary rocks that constitute silicate catchment and part of carbonate catchment unconformably
Table 1. Comparison of the physical characteristics and mean discharge for the Odae and Jijang catchments (Water Management Information System: http://www.wamis.go.kr).

\begin{tabular}{lrr}
\hline Tributary & $\begin{array}{c}\text { Odae } \\
\text { (silicate) }\end{array}$ & $\begin{array}{c}\text { Jijang } \\
\text { (carbonate) }\end{array}$ \\
\hline Catchment area $\left(\mathrm{km}^{2}\right)$ & 452 & 225 \\
Total stream length $(\mathrm{km})$ & 521 & 464 \\
1st order stream length $(\mathrm{km})$ & 272 & 230 \\
Main channel* length $(\mathrm{km})$ & 44 & 37 \\
Mean width $(\mathrm{m})$ & 8.2 & 5.6 \\
Mean discharge $\left(\mathrm{m}^{3} \mathrm{~s}^{-1}\right)$ & 7 & 3 \\
\hline
\end{tabular}

* Main channel corresponds to 5th order stream in both catchments.

overlie the Ordovician limestone. In the silicate catchment, the thickness of sedimentary rocks is known to be greater than $\sim 500 \mathrm{~m}$ and both spring and stream water samples were collected on this sedimentary formation. The elevation of the study sites ranges from 340 to $1560 \mathrm{~m}$ for the Odae and from 260 to $1570 \mathrm{~m}$ for the Jijang catchment. The vegetation in the study area consisted mainly of C3 plants (mixed deciduous broadleaf and conifer forests) with seasonally cultivated crops such as rice, barley, corn, and cabbages. Table 1 presents information of the two streams (Water Management Information System: http://www.wamis.go.kr).

\subsection{Sampling and analytical procedures}

Water sampling and in-situ measurements of geochemical parameters were conducted at four locations on a biweekly basis for 18 months (July 2004 to December 2005). Water was collected from the two perennial springs and the outlet of the main channel (fifth-order stream) in both catchments. In the silicate catchment (Odae), samples were collected from a spring located at the bottom of a sandstone cliff from which water was discharging at $\sim 37 \mathrm{~m}^{3} \mathrm{day}^{-1}$. In the carbonate catchment (Jijang), a perennial spring flowing from the base of a carbonate cliff was chosen. Although sampling began in July 2004, this study focused on the data from 2005 because a more complete dataset was available in terms of measured parameters and seasonal coverage. An independent isotope survey was conducted on soil organic materials and leaf litters at the studied catchments in summer, 2011. Samples were collected near the spring waters, and from the deposits near the river outlets (close to the stream sample locations) to obtain representative soil organic materials for the entire catchments.

Temperature, $\mathrm{pH}$, dissolved oxygen (DO), and electrical conductivity (EC) were measured on site during water sampling using a YK-2001PH portable meter (Lutron Electronic CO., Taiwan). Alkalinity was measured on site by titration with $0.05 \mathrm{~N} \mathrm{HCl}$ according to the Gran method (Rounds and Wilde, 2001). To fully characterize the carbonate system, 

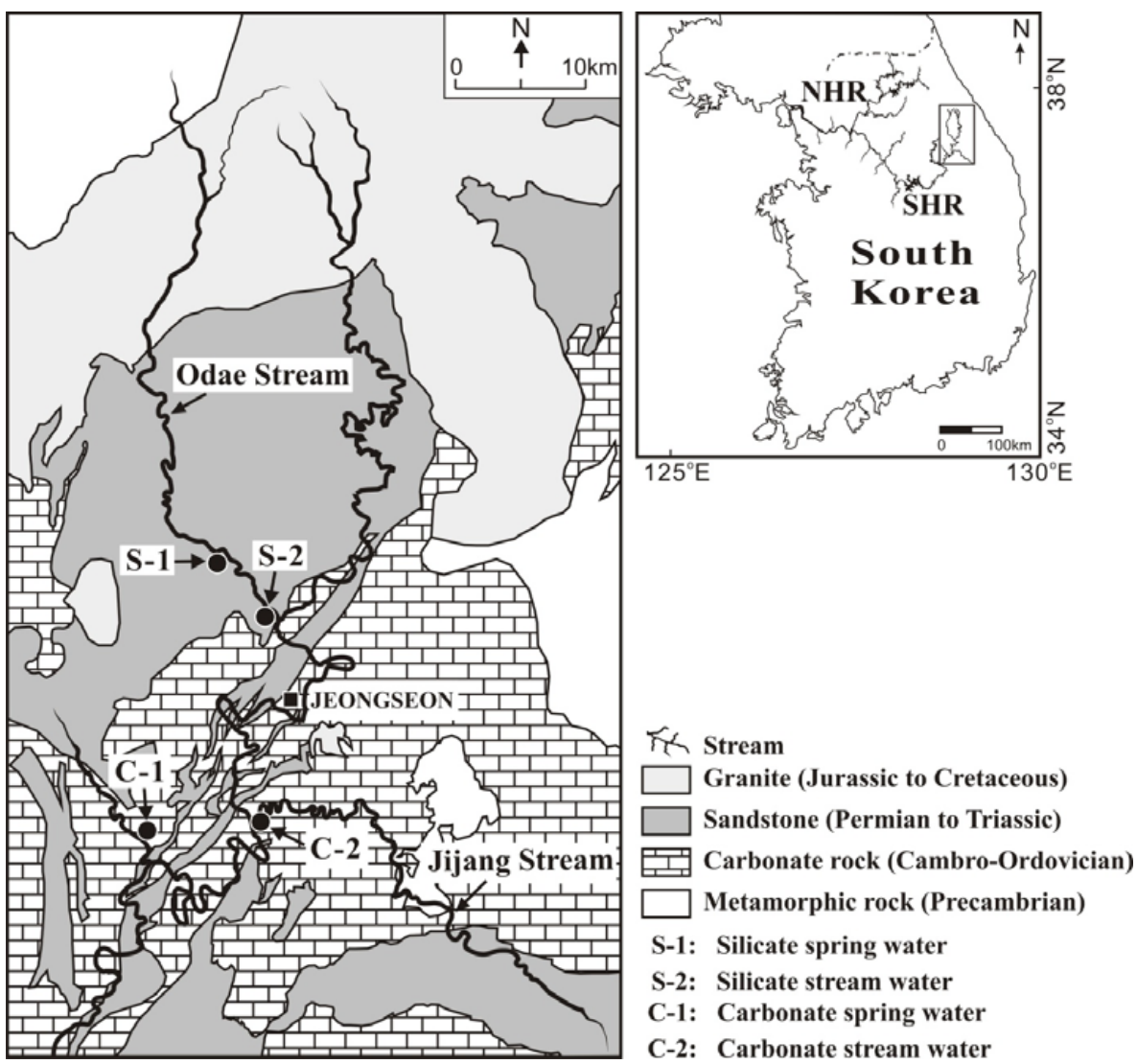

Fig. 1. Map showing the basement lithology and sampling locations of the studied catchments, two uppermost tributaries of the South Han River. Spring and stream waters in the silicate catchment were collected at S-1 and S-2, respectively; spring and stream waters in the carbonate catchment were collected at C-1 and C-2. NHR and SHR represent the North Han River and the South Han River, respectively.

ion activities were evaluated by PHREEQC (Parkhurst and Appelo, 1999). The partial pressure of $\mathrm{CO}_{2}\left(p \mathrm{CO}_{2}\right)$ was calculated by the speciation outputs from PHREEQC. The temperature-dependent equilibrium constants for the three species $\left(\mathrm{H}_{2} \mathrm{CO}_{3}, \mathrm{HCO}_{3}^{-}\right.$, and $\left.\mathrm{CO}_{3}^{2-}\right)$ of the DIC summarized by Langmuir (1997) were used to calculate the activities of the three species.

For $\delta^{13} \mathrm{C}_{\text {DIC }}$ analysis, water samples were collected using two evacuated glass bottles $(150 \mathrm{ml})$ pre-loaded with $85 \%$ phosphoric acid and a magnetic stir bar, as reported by Atekwana and Krishnamurthy (1998). Water sampling was carried out in the field using a syringe with a 0.45 $\mu \mathrm{m}$ Millipore membrane filter. Samples were kept refrigerated until analysis. The DIC in water samples was converted into $\mathrm{CO}_{2}$ gas by a gas-evolution technique (Atekwana and Krishnamuthy, 1998). The $\mathrm{CO}_{2}$ gas was then extracted and cryogenically purified. Next, the $\delta^{13} \mathrm{C}_{\text {DIC }}$ of the evolved $\mathrm{CO}_{2}$ was measured using an Optima isotoperatio mass spectrometer (GV Instruments, UK) at Chungnam National University. Soil organic materials and leaf litters were dried at $50^{\circ} \mathrm{C}$ for $24 \mathrm{~h}$ and powdered. The mixtures of organic materials and soils were treated with dilute
$\mathrm{HCl}$ to remove carbonates, then rinsed with deionized water, and dried. The carbon isotope compositions of soil organic materials and leaf litters were determined using an isotope ratio mass spectrometer (GV IsoPrime, UK) interfaced with elemental analyzer (EuroVector EuroEA3000 series, Italy) at the Korea Basic Science Institute. Carbon isotopic ratios are reported using standard $\delta$ notation, in per mil (\%o) differences relative to the Vienna Pee Dee belemnite (VPDB) standard, i.e. $\delta(\% o)=\left(R_{\text {sample }} / R_{\text {standard }}-1\right) \times 1000$, where $R$ represents ${ }^{13} \mathrm{C} /{ }^{12} \mathrm{C}$. The analytical reproducibility was $\pm 0.2 \%$ based on repeated analyses of laboratory and NBS standards.

\section{Results}

Figure 2 shows the precipitation, $\delta^{13} \mathrm{C}_{\mathrm{DIC}}$, and $p \mathrm{CO}_{2}$ of the four water types. Ranges and averages of the measured parameters are shown in Table 2. The $\mathrm{pH}$ and alkalinities were consistently higher in the carbonate spring. Remarkable seasonal variations in $\delta^{13} \mathrm{C}_{\mathrm{DIC}}$ were observed especially in the silicate spring waters. $\delta^{13} \mathrm{C}_{\mathrm{DIC}}$ of the silicate spring (average 


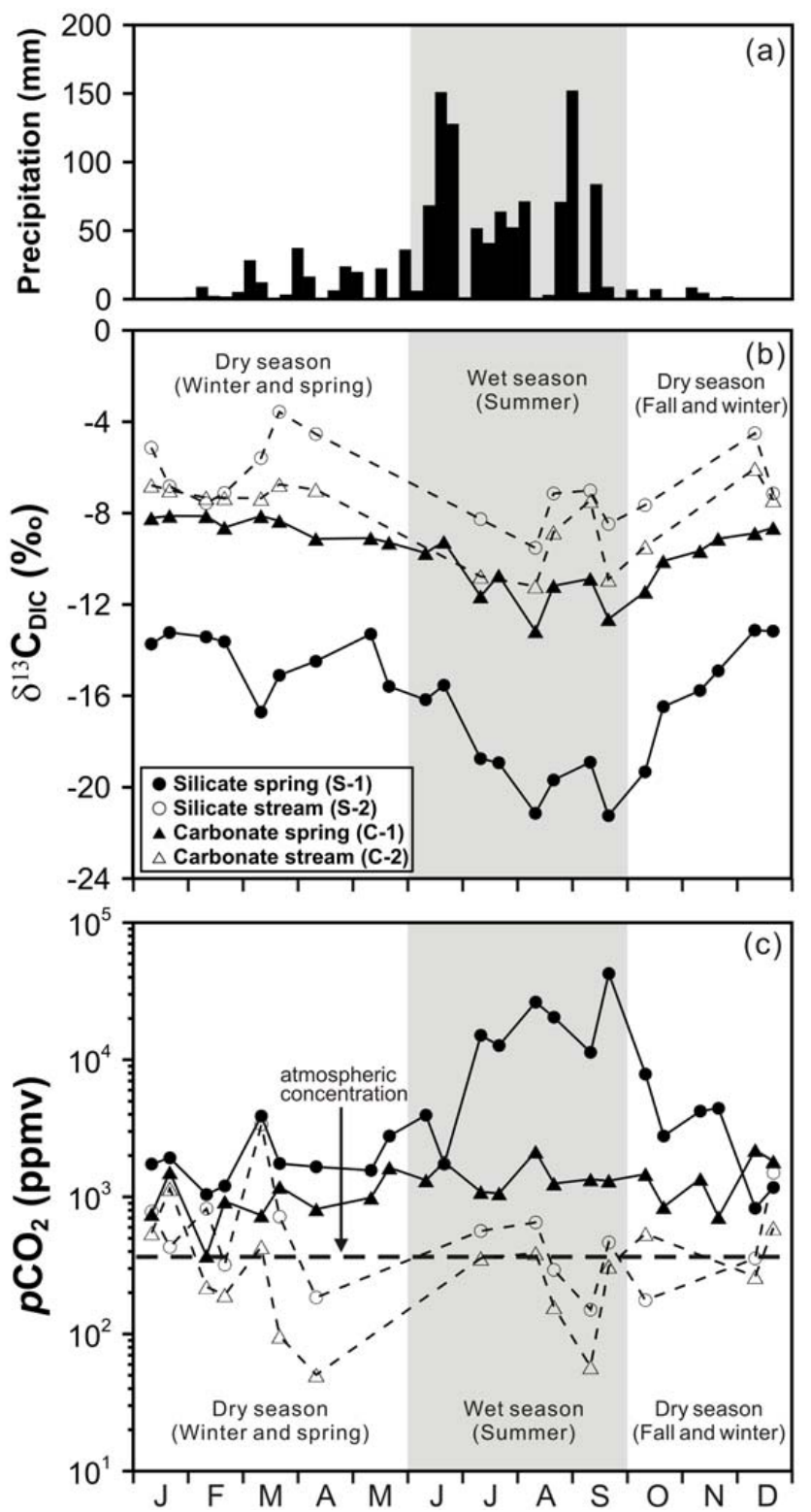

Fig. 2. Figures showing (a) monthly precipitation, (b) $\delta^{13} \mathrm{C}_{\mathrm{DIC}}$, and (c) $p \mathrm{CO}_{2}$ of waters from the silicate and carbonate catchments during 2005.

of $-16.2 \pm 2.7 \%$ ) was much lower than the carbonate spring (average of $-9.7 \pm 1.5 \%$ ). The $p \mathrm{CO}_{2}$ in the silicate spring was higher than that of the carbonate spring water (Fig. 2c). The $\delta^{13} \mathrm{C}_{\mathrm{DIC}}$, alkalinity, and $\mathrm{pH}$ were the major parameters used to distinguish silicate and carbonate spring waters. The two spring waters were distinguished by a $\mathrm{pH}$ of 7 , and the silicate spring had a wider range than the carbonate spring (Fig. 3). The carbonate spring water had greater alkalinity with larger variability, whereas the variability of the silicate spring was limited.

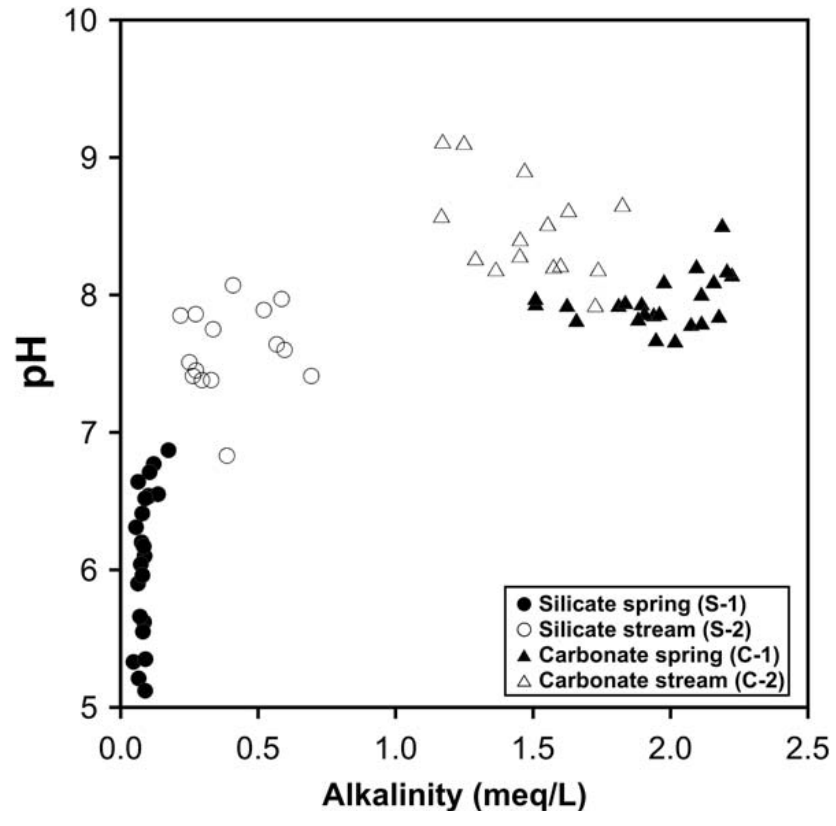

Fig. 3. Cross plot of alkalinity vs. $\mathrm{pH}$ in spring and stream waters. Note that the four different types of water are clearly distinguished in this figure.

The $\mathrm{pH}$, alkalinity, and $\mathrm{EC}$ were higher in the carbonate stream. $\delta^{13} \mathrm{C}_{\mathrm{DIC}}$ was slightly higher in the silicate stream $(-6.9 \pm 1.6 \%)$ than the carbonate stream $(-7.8 \pm 1.5 \%$ ) The $p \mathrm{CO}_{2}$ was higher in the silicate stream than in the carbonate stream. DO was mostly supersaturated with respect to atmospheric $\mathrm{O}_{2}$, showing the average dissolved $\mathrm{O}_{2}$ saturation $\left(\mathrm{DO}_{\text {sat }}\right)$ of $\sim 1.2$ in both streams. Alkalinity was the parameter that differentiated stream waters (Fig. 3). Both stream waters had higher $\mathrm{pH}$ than the respective spring water in each catchment. Compared to the respective spring water, alkalinity was higher in the silicate stream, but was lower in the carbonate stream. Notably, in the carbonate catchment, alkalinity in the stream decreased with simultaneous increase in EC compared to the spring waters. Alkalinity and EC generally correlate positively if mineral weathering is the major control. However, Hill and Neal (1997) reported a negative correlation between alkalinity and EC in stream waters of small headwater catchments, i.e. EC increases were associated with alkalinity decreases when soil- and surfacederived components (nutrients and organic acids) increased in the stream waters.

$\delta^{13} \mathrm{C}$ of soil organic carbon was from -27.1 to $-22.1 \%$. $\delta^{13} \mathrm{C}$ tends to increase with the soil depth and no distinction in $\delta^{13} \mathrm{C}$ of soil organic carbon was observed between two catchments. The leaf litters (relatively recent organic components) have the similar $\delta^{13} \mathrm{C}$ in both catchments ranging from -31.1 to $-29.3 \%$. 
Table 2. Statistical summary of geochemical parameters measured from springs and streams in the study area.

\begin{tabular}{|c|c|c|c|c|c|c|c|c|c|c|c|c|c|c|c|c|}
\hline \multirow{3}{*}{ Parameters } & \multicolumn{8}{|c|}{ Silicate catchment } & \multicolumn{8}{|c|}{ Carbonate catchment } \\
\hline & \multicolumn{4}{|c|}{ Spring water } & \multicolumn{4}{|c|}{ Stream water } & \multicolumn{4}{|c|}{ Spring water } & \multicolumn{4}{|c|}{ Stream water } \\
\hline & Min* & Max* & Aver* & $\mathrm{SD}^{*}$ & Min* & Max* & Aver* & $\mathrm{SD}^{*}$ & Min* & Max* & Aver* & $\mathrm{SD}^{*}$ & Min* & Max* & Aver* & $\mathrm{SD}^{*}$ \\
\hline $\begin{array}{l}\text { Temp. } \\
\left({ }^{\circ} \mathrm{C}\right)\end{array}$ & 8.8 & 12.7 & 10.7 & 1.3 & 0.4 & 28.0 & 11.0 & 8.9 & 8.9 & 14.3 & 11.6 & 1.9 & 0.3 & 28.0 & 13 & 8.4 \\
\hline $\begin{array}{l}\mathrm{EC} \\
\left(\mu \mathrm{Scm}^{-1}\right)\end{array}$ & $\mathrm{ND}^{* *}$ & $\mathrm{ND}^{* *}$ & $\mathrm{ND}^{* *}$ & & 11 & 122 & 64 & 31 & 171 & 389 & 254 & 62 & 222 & 433 & 301 & 60 \\
\hline $\begin{array}{l}\text { Alk } \\
\left(\text { meq }^{-1}\right)\end{array}$ & 0.05 & 0.17 & 0.09 & 0.0 & 0.22 & 0.74 & 0.44 & 0.15 & 1.50 & 2.21 & 1.96 & 0.21 & 1.18 & 1.83 & 1.46 & 0.16 \\
\hline $\begin{array}{l}\text { DIC } \\
\left(\mathrm{mg} \mathrm{l}^{-1}\right)\end{array}$ & 5.6 & 103.3 & 22.7 & 23.3 & 13.7 & 45.5 & 26.0 & 10.0 & 93.1 & 137.9 & 121.8 & 12.8 & 71.3 & 110.2 & 91.0 & 12.0 \\
\hline
\end{tabular}

* Min, Max, Aver, and SD represent minimum, maximum, average, and standard deviation, respectively. ${ }^{*}$ ND: not determined.

\section{Discussion}

\subsection{Sources of spring water DIC}

The clear distinction in geochemical and carbon isotope characteristics between the two spring waters indicated that the springs may represent the characteristics of the groundwater in each catchment. To examine this, the expected carbon isotopic composition was calculated for the groundwater DIC originating exclusively from soil $\mathrm{CO}_{2}$ (silicate catchment) and from a 1:1 mixture of soil $\mathrm{CO}_{2}$ and carbonate minerals (carbonate catchment). The calculation was made using the measured $\delta^{13} \mathrm{C}$ of soil organic matter in both catchments ranging from -27 to $-22 \%$ and the temperature dependence of carbon isotope fractionation between $\mathrm{CO}_{2}$ and $\mathrm{H}_{2} \mathrm{CO}_{3} / \mathrm{HCO}_{3}^{-}$(Zhang et al., 1995). The ratio between $\mathrm{H}_{2} \mathrm{CO}_{3}$ and $\mathrm{HCO}_{3}^{-}$was calculated using $K_{1} / a_{\mathrm{H}^{+}}$, where $K_{1}$ is the first dissociation constant of $\mathrm{H}_{2} \mathrm{CO}_{3}$, and $a_{\mathrm{H}^{+}}$was calculated from the measured $\mathrm{pH}$. The expected $\delta^{13} \mathrm{C}_{\text {DIC }}$ in the silicate spring (with $31 \% \mathrm{HCO}_{3}^{-}$and $69 \%$ $\mathrm{H}_{2} \mathrm{CO}_{3}$ at the average $\mathrm{pH}$ of 6.1) derived from soil $\mathrm{CO}_{2}$ was $-25.1 \sim-20.1 \%$, which was lower than the measured average value of $-16.2 \pm 2.7 \%$. For the carbonate spring, the expected $\delta^{13} \mathrm{C}_{\text {DIC }}\left(97 \% \mathrm{HCO}_{3}^{-}\right.$at the average $\mathrm{pH}$ of 8.0$)$ derived from 1:1 mixture of soil $\mathrm{CO}_{2}$ and carbonate minerals was $-9.1 \sim-6.6 \%$, which was closer to or higher than the measured average value $(-9.7 \pm 1.5 \%$ ) .

The discrepancy between measured and expected $\delta^{13} \mathrm{C}_{\text {DIC }}$ may be related to degassing of $\mathrm{CO}_{2}$ from the water. While diffusive efflux of soil $\mathrm{CO}_{2}$ may impart ${ }^{13} \mathrm{C}$ enrichment (e.g. Chap. 5 of Clark and Fritz, 1997), the major ${ }^{13} \mathrm{C}$ enrichment likely occurred during $\mathrm{CO}_{2}$ degassing associated with the groundwater discharge (e.g. Johnson et al., 2008).
Degassing can explain the greater discrepancy observed in the silicate catchment. Because the proportion of dissolved $\mathrm{CO}_{2}\left(\mathrm{H}_{2} \mathrm{CO}_{3}\right)$ in the total DIC was large in the silicate spring due to relatively low $\mathrm{pH}$, the effect of $\mathrm{CO}_{2}$ degassing was more significant. To verify the effect of $\mathrm{CO}_{2}$ degassing on $\delta^{13} \mathrm{C}_{\text {DIC }}$ of the silicate spring, the method from Doctor et al. (2008) was applied. They reported that the increase in $\delta^{13} \mathrm{C}_{\text {DIC }}$ per natural log-unit decrease of excess $p \mathrm{CO}_{2}$ was $2.4 \%$, where excess $p \mathrm{CO}_{2}$ is the measured $p \mathrm{CO}_{2}$ normalized to the expected $p \mathrm{CO}_{2}$ at atmospheric equilibrium. In this study, the relationship was calculated as a $2.3 \pm 0.2 \%$ increase per unit decrease of excess $p \mathrm{CO}_{2}$, indicating that the variability in silicate spring $\delta^{13} \mathrm{C}_{\mathrm{DIC}}$ closely followed the reported change associated with the $\mathrm{CO}_{2}$ degassing. DIC in the carbonate spring water consisted primarily of $\mathrm{HCO}_{3}^{-}$; therefore, the effect of $\mathrm{CO}_{2}$ degassing and associated enrichment of ${ }^{13} \mathrm{C}$ was not clearly observed. Unlike the silicate spring, the expected $\delta^{13} \mathrm{C}_{\text {DIC }}$ in the carbonate spring was higher than the measured, which may indicate that the assumed stoichiometric proportion of carbonate-derived DIC $(\sim 50 \%)$ could be an over-estimation. In summary, the spring waters may well represent the groundwater component modified by $\mathrm{CO}_{2}$ degassing in the silicate catchment and variable carbonate input in the carbonate catchment.

\subsection{The evolution of $\delta^{13} \mathrm{C}_{\mathrm{DIC}}$ in stream waters}

Because the spring waters likely represent the source groundwater composition, it is informative to compare spring and stream waters to understand processes occurring along the hydrological pathways. Although the variability in $\delta^{13} \mathrm{C}_{\text {DIC }}$ between stream and spring waters was generally correlated in each catchment (with $r^{2}=0.62$ in the carbonate and $r^{2}=0.31$ 

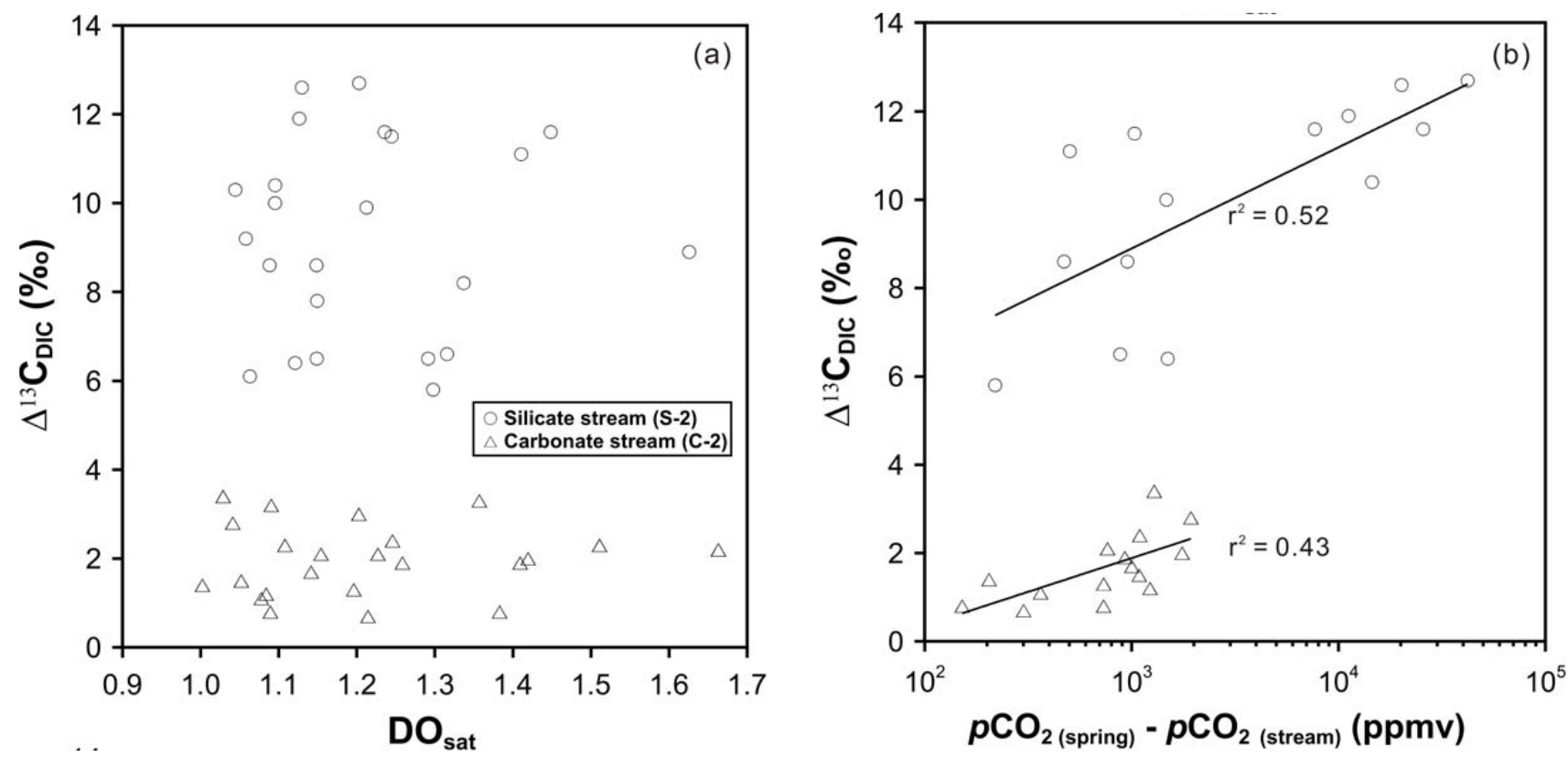

Fig. 4. Cross plots of (a) $\mathrm{DO}_{\text {sat }}$ vs. $\Delta^{13} \mathrm{C}_{\mathrm{DIC}}\left[\delta^{13} \mathrm{C}_{\mathrm{DIC}}\right.$ (stream water) $-\delta^{13} \mathrm{C}_{\mathrm{DIC}}$ (spring water) $]$, and (b) $\left[p \mathrm{CO}_{2}\right.$ (spring water) $-p \mathrm{CO} 2$ (stream water)] vs. $\Delta^{13} \mathrm{C}_{\mathrm{DIC}}$.

in the silicate catchment), the difference between catchments was reduced $(\sim 0.9 \%$ o between streams compared to $\sim 6.5 \%$ o between springs) and DIC was more enriched in ${ }^{13} \mathrm{C}$ in stream waters. The increase in $\delta^{13} \mathrm{C}_{\mathrm{DIC}}$ was likely related to aquatic photosynthesis and $\mathrm{CO}_{2}$ degassing.

To examine the relative importance of aquatic photosynthesis and $\mathrm{CO}_{2}$ degassing, the difference in $\delta^{13} \mathrm{C}_{\text {DIC }}$ between the spring and stream waters $\left(\Delta^{13} \mathrm{C}_{\mathrm{DIC}}\right)$ was plotted against the $\mathrm{DO}_{\text {sat }}$ in stream waters (Fig. 4a) and the difference in $p \mathrm{CO}_{2}$ between the spring and stream waters $\left(\Delta p \mathrm{CO}_{2}\right)$ (Fig. $\left.4 \mathrm{~b}\right)$. Because the stream waters were mostly over-saturated with $\mathrm{O}_{2}$ relative to atmospheric equilibrium, photosynthesis was assumed to be prevalent, and associated ${ }^{13} \mathrm{C}$ enrichment was expected. However, the correlation between $\Delta^{13} \mathrm{C}_{\mathrm{DIC}}$ and $\mathrm{DO}_{\text {sat }}$ was low $\left(r^{2}<0.1\right)$, indicating that aquatic photosynthesis may not have been the major process for ${ }^{13} \mathrm{C}$ enrichment. In addition, if photosynthesis resulted in ${ }^{13} \mathrm{C}$ enrichment, there would have been a seasonal difference in $\delta^{13} \mathrm{C}_{\mathrm{DIC}}$ because photosynthesis is more intense in summer than in winter. However, the magnitude of ${ }^{13} \mathrm{C}$ enrichment was similar regardless of the season.

In contrast, $\Delta^{13} \mathrm{C}_{\mathrm{DIC}}$ exhibited a higher correlation $\left(r^{2}=0.52\right.$ and 0.43$)$ with $\Delta p \mathrm{CO}_{2}$ in both catchments. Therefore, a simplified interpretation regarding the enrichment of ${ }^{13} \mathrm{C}$ in stream water DIC is that it was caused mainly due to $\mathrm{CO}_{2}$ degassing along the pathways from the groundwater reservoirs to the stream. In the carbonate catchment, $\Delta{ }^{13} \mathrm{C}_{\mathrm{DIC}}$ was comparatively small because of the minor proportion of dissolved $\mathrm{CO}_{2}$ in the total DIC; thus, the effect of $\mathrm{CO}_{2}$ degassing from the groundwater was smaller than that in the silicate catchment. Moreover, due to the slight undersaturation with $\mathrm{CO}_{2}$ in the carbonate stream, $\mathrm{CO}_{2}$ dissolution may also have occurred that led to a different degree of ${ }^{13} \mathrm{C}$ enrichment compared to that expected from $\mathrm{CO}_{2}$ degassing.

\subsection{Seasonal variation in $\delta^{13} C_{\text {DIC }}$ and carbonate chemistry}

The spring and stream samples exhibited well-defined seasonal variations characterized by low $\delta^{13} \mathrm{C}_{\mathrm{DIC}}$ during summer (June to September) and high $\delta^{13} \mathrm{C}_{\text {DIC }}$ during winter (November to February) (Fig. 2b). In addition, $p \mathrm{CO}_{2}$ showed a seasonal dependence, with higher values during June-October and lower values during November-March, especially in the silicate spring water (Fig. 2c). In the study area, the observed seasonality could have been due to (1) the seasonal change in metabolic activity related to changes in temperature and (2) changes in the water regime related to precipitation patterns.

Because both stream waters were assumed to be dominantly photosynthetic, the higher $p \mathrm{CO}_{2}$ during summer does not support in-situ production, but likely reflects $\mathrm{CO}_{2}$ transport from soils via groundwater discharge associated with the enhanced microbial and root respiration during the season (Barth and Veizer, 1999; Hope et al., 2004; Yao et al., 2007). The addition of soil $\mathrm{CO}_{2}$ via soil/groundwater resulted in low $\delta^{13} \mathrm{C}_{\mathrm{DIC}}$ of the water. A negative correlation $\left(r^{2}=0.92\right)$ between $\delta^{13} \mathrm{C}_{\mathrm{DIC}}$ and $p \mathrm{CO}_{2}$ in the spring samples in the silicate catchment indicates that the changes in the amount of soilderived $\mathrm{CO}_{2}$ were the main cause of seasonality in $\delta^{13} \mathrm{C}_{\mathrm{DIC}}$ 

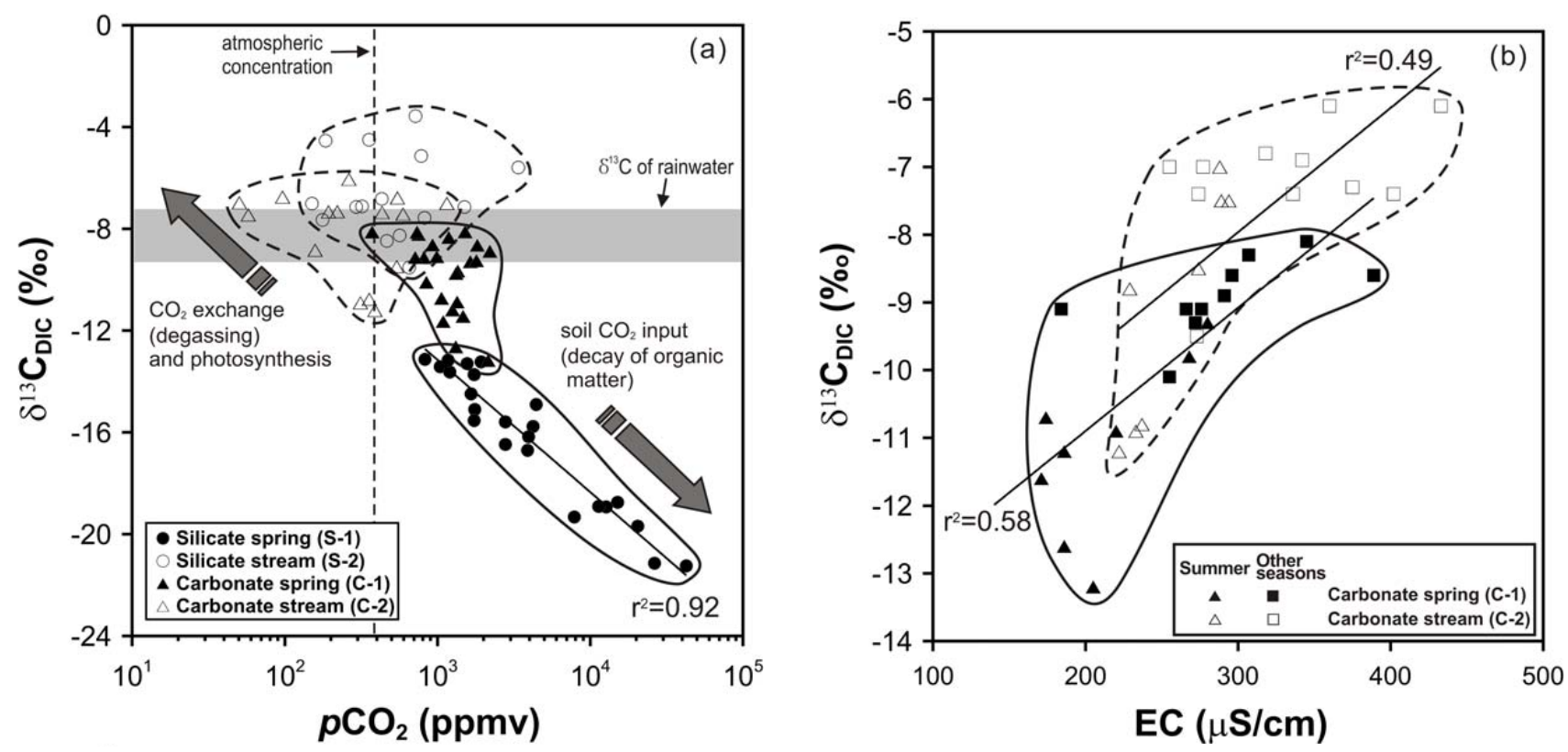

Fig. 5. Cross plots of (a) $p \mathrm{CO}_{2}$ vs. $\delta^{13} \mathrm{C}_{\mathrm{DIC}}$, and (b) EC vs. $\delta^{13} \mathrm{C}_{\mathrm{DIC}}$. Summer: June through September. The $\delta^{13} \mathrm{C}_{\mathrm{DIC}}$ value of rainwater is from Zhang et al. (1995).

(Fig. 5a). The correlation between $\delta^{13} \mathrm{C}_{\text {DIC }}$ and $p \mathrm{CO}_{2}$ in other types of water was not as obvious as in the spring samples in the silicate catchment. In the carbonate catchment, the changes in $\delta^{13} \mathrm{C}_{\mathrm{DIC}}$ were positively correlated with $\mathrm{EC}$ in the spring $\left(r^{2}=0.58\right)$ and stream $\left(r^{2}=0.49\right)$ waters (Fig. $\left.5 b\right)$, and waters with low EC occurred during the summer when $\delta^{13} \mathrm{C}_{\mathrm{DIC}}$ was also low. EC increased as the residence time of water in soil and groundwater reservoirs increased; thus, during summer, EC decreased due to the higher precipitation and rapid turnover of subsurface water (Clark and Fritz, 1997). This indicates that the seasonality of $\delta^{13} C_{\text {DIC }}$ in the carbonate catchment was related to the change of the water regime due to seasonal precipitation patterns.

Precipitation, which was measured at the Yeongweol meteorological station about $40 \mathrm{~km}$ from the study area (data from Korea Meteorological Administration, KMA: http://www.kma.go.kr), varied throughout the study period (Fig. 2a). The average monthly precipitation during summer and early fall (June to September) was $249 \mathrm{~mm}$, but for the rest of the year (October to May) it was only $32 \mathrm{~mm}$. The seasonal variation of precipitation roughly coincided with the fluctuations in $\delta^{13} \mathrm{C}_{\text {DIC }}$ (Fig. 2b) of all water samples and in $\mathrm{EC}$ of the carbonate catchment. During the dry season, pore water has a long residence time in the soil horizon, allowing for an extended exchange of $\mathrm{CO}_{2}$ with the atmosphere through the soil zone, thereby increasing $\delta^{13} \mathrm{C}_{\mathrm{DIC}}$ and $\mathrm{EC}$ of the soil water. In contrast, during the wet season, the frequent infiltration of rainwater into the soil and the outflow of interstitial soil waters from the vadose zone result in a shorter residence time for soil water and limit $\mathrm{CO}_{2}$ exchange with the atmosphere. Therefore, soil water in the wet season displays lower $\delta^{13} \mathrm{C}_{\mathrm{DIC}}$ and $\mathrm{EC}$ than does soil water during the dry season (Amiotte-Suchet et al., 1999). The transport of $\mathrm{CO}_{2}$ produced by increased soil respiration via soil/groundwater with distinct EC is facilitated by the concentrated precipitation in summer. The effect of $p \mathrm{CO}_{2}$ was not clearly observed in the waters from the carbonate catchment due to lower $\mathrm{CO}_{2} / \mathrm{HCO}_{3}^{-}$ratios, but the analogous effect associated with seasonal changes in soil respiration and water regime can be expressed by EC vs. $\delta^{13} \mathrm{C}_{\text {DIC }}$ plots (Fig. 5b).

\subsection{DIC export from the river system}

The importance of $\mathrm{CO}_{2}$ degassing was suggested from the previous discussion on the changes in $\delta^{13} \mathrm{C}_{\mathrm{DIC}}$ of spring and stream waters. The calculated excess $p \mathrm{CO}_{2}$ was 19.8 in the silicate spring, 3.3 in the carbonate spring, 1.9 in the silicate stream, and 0.9 in the carbonate stream (all as annual averages in 2005). Except for the carbonate stream, the studied waters were over-saturated with $\mathrm{CO}_{2}$ and assumed to act as the source of atmospheric $\mathrm{CO}_{2}$ (Yao et al., 2007). Although the excess $p \mathrm{CO}_{2}$ in the carbonate stream was lower than 1 , indicating possible invasion of atmospheric $\mathrm{CO}_{2}$, its DIC was still depleted in ${ }^{13} \mathrm{C}$ compared with atmospherederived DIC $\left(\sim 0 \%\right.$, assuming $\delta{ }^{13} \mathrm{C}$ of atmospheric $\mathrm{CO}_{2}$ to be $-7.8 \%$ from Brunet et al., 2005).

To quantitatively determine the amount of $\mathrm{CO}_{2}$ degassing, the following flux equation was applied:

$F=k_{\mathrm{CO}_{2}}\left(C_{\mathrm{eq}}-C\right)$,

where $F$ is the diffusive flux of $\mathrm{CO}_{2}$ to the atmosphere, $k_{\mathrm{CO}_{2}}$ is the gas transfer coefficient, and $C_{\mathrm{eq}}$ and $C$ are the dissolved 
$\mathrm{CO}_{2}$ concentrations in equilibrium with the atmosphere and as measured, respectively. Because $k_{\mathrm{CO}_{2}}$ was not determined in this study, $F$ was calculated for all possible ranges of $k_{\mathrm{CO}_{2}}$ using various relationships between wind speed and $k_{\mathrm{CO}_{2}}$. The estimated $k_{\mathrm{CO}_{2}}$ ranged from $0.14 \mathrm{md}^{-1}$ (based on Wanninkhof, 1992) to $1.92 \mathrm{~m} \mathrm{~d}^{-1}$ (based on Borges et al., 2004) at the mean wind speed of $1.54 \mathrm{~m} \mathrm{~s}^{-1}$ during the study period (from KMA). The carbon flux to the atmosphere was estimated at 220 to $3000 \mathrm{gC} \mathrm{m}^{-2} \mathrm{yr}^{-1}$ for the silicate spring water and 30 to $430 \mathrm{gC} \mathrm{m}^{-2} \mathrm{yr}^{-1}$ for the carbonate spring water. The silicate stream water had a carbon flux of 10 to $150 \mathrm{gC} \mathrm{m}^{-2} \mathrm{yr}^{-1}$, whereas the carbonate stream water may have incorporated atmospheric $\mathrm{CO}_{2}$ at rates of 2 to $30 \mathrm{gC} \mathrm{m}^{-2} \mathrm{yr}^{-1}$. Although the estimated carbon flux was within the range reported in other studies (Richey et al., 2002; Yao et al., 2007; Brunet et al., 2009; Dubois et al., 2010), it is notable that the effect varied depending on the catchment lithology. In terms of the atmospheric $\mathrm{CO}_{2}$ budget, the silicate catchments were assumed to act as stronger sources than the carbonate catchments, and carbonate stream waters may even act as a minor sink.

Table 3 presents a comprehensive carbon budget for the studied river systems. A few assumptions were made to derive the catchment-scale carbon budget. First, the data measured at the mouth of the stream collectively represent the carbon exchange characteristics of the stream waters, except for the first-order streams in the catchment. The firstorder streams likely retained characteristics of the groundwater, which diminish in the higher-order streams (Johnson et al., 2008). Second, the spring waters represent the subsurface waters in each catchment, as discussed in Sect. 4.1. Third, the stream waters consisted primarily of discharged groundwater, although the hydrograph separation of the studied streams was not available.

The DIC discharge via the stream was the largest component, ranging from $12.7 \mathrm{gC} \mathrm{m}^{-2} \mathrm{yr}^{-1}$ in the silicate catchment to $38.3 \mathrm{gC} \mathrm{m}^{-2} \mathrm{yr}^{-1}$ in the carbonate catchment. $\mathrm{CO}_{2}$ degassing from the stream (higher than second order) was 0.05 to $0.68 \mathrm{gC} \mathrm{m}^{-2} \mathrm{yr}^{-1}$ in the silicate catchment, whereas $\mathrm{CO}_{2}$ dissolution of -0.01 to $-0.17 \mathrm{gC} \mathrm{m}^{-2} \mathrm{yr}^{-1}$ occurred in the carbonate stream. Notably, the estimated $\mathrm{CO}_{2}$ degassing associated with the groundwater discharge was significant, 1.1 to $14.9 \mathrm{gC} \mathrm{m}^{-2} \mathrm{yr}^{-1}$ in the silicate catchment and 0.17 to $2.4 \mathrm{gC} \mathrm{m}^{-2} \mathrm{yr}^{-1}$ in the carbonate catchment. Depending on the adopted $k_{\mathrm{CO}_{2}}$, the $\mathrm{CO}_{2}$ degassing (from both stream and groundwater) may have been responsible for $8-55 \%$ of the total DIC export from the silicate catchment, whereas it took up only $0.4-5.6 \%$ in the carbonate catchment. The results clearly indicate that $\mathrm{CO}_{2}$ degassing at the interface between groundwater and streams in headwater regions needs to be considered to derive a reliable carbon budget in river systems, especially in silicate-dominant catchments.

The carbon budget estimates obtained in this study are different from those in other studies because the $\mathrm{CO}_{2}$ degassing during groundwater discharge into the stream was
Table 3. Estimated annual carbon budget of the studied catchments. All units are $\mathrm{gC} \mathrm{m}^{-2} \mathrm{yr}^{-1}$.

\begin{tabular}{lll}
\hline Stream & \multicolumn{1}{c}{$\begin{array}{c}\text { Odae } \\
\text { (silicate) }\end{array}$} & $\begin{array}{c}\text { Jijang } \\
\text { (carbonate) }\end{array}$ \\
\hline DIC discharge via streams & 12.7 & 38.3 \\
$\mathrm{CO}_{2}$ degassing from streams* & $0.05 \sim 0.68$ & $-0.01 \sim-0.17$ \\
$\mathrm{CO}_{2}$ degassing from groundwater* & $1.1 \sim 14.9$ & $0.17 \sim 2.4$ \\
\hline
\end{tabular}

* Fluxes were calculated for the range of gas transfer coefficient.

considered. However, uncertainties may exist in the estimation of $\mathrm{CO}_{2}$ evasion from groundwater. For example, there is uncertainty related to the characterization of the interface between groundwater and the stream because the quantity of $\mathrm{CO}_{2}$ degassing depends on the dimension of the water surface. The interface was assumed to be the first-order stream where the immediate confluence of groundwater occurs. Previous studies (Johnson et al., 2008; Öquist et al., 2009) reported that the evasion of $\mathrm{CO}_{2}$, accompanied by subsurface water input, was concentrated along a short distance $(\sim 200 \mathrm{~m})$ of stream water from the confluence, which may substantiate this assumption. Another uncertainty is related to the proportion of groundwater components in the stream. Stream waters may contain variable amounts of surface runoff and direct precipitation. Hydrograph separation using various tracers can give quantitative estimates of these water components (Genereux and Hooper, 1998). Because it is assumed that the stream water was mostly derived from groundwater, the $\mathrm{CO}_{2}$ degassing estimates in this study likely represent the highest possible amount. Moreover, the biweekly sampling adopted in this study possibly induce uncertainty in that rapid changes in water regimes associated with storm events may not be properly captured. A continuous monitoring of key variables (that can be used as surrogate for important water properties) of river waters is suggested for a more comprehensive and reliable understanding of river dynamics and associated carbon exchanges (e.g. Waldron et al., 2007).

\section{Conclusions}

The uppermost tributaries of the SHR, South Korea, provided an ideal natural setting to examine the effects of catchment lithology, seasonality in metabolic activities and water regimes, and atmospheric exchange on $\delta^{13} \mathrm{C}_{\mathrm{DIC}}$ and carbonate chemistry. $\delta^{13} \mathrm{C}_{\text {DIC }}$ of the groundwater, represented by that of spring waters, clearly exhibited the effects of catchment lithologies, i.e. silicate vs. carbonate, on soil carbon dynamics. Seasonal variations were obvious in relation to the temperature-induced changes in metabolic activities in soils and the precipitation-induced changes in hydrologic regimes. Both stream waters were enriched with ${ }^{13} \mathrm{C}$ compared to the 
respective spring waters. This was in part due to aquatic photosynthesis, but was primarily caused by $\mathrm{CO}_{2}$ degassing, which occurred during groundwater discharge and stream flow, but the magnitude was far greater from the groundwater. The estimated carbon budget depended on the catchment lithology. In the silicate catchment, $\mathrm{CO}_{2}$ degassing associated with the groundwater discharge could be as high as the DIC discharge via the rivers. In contrast, DIC discharge via stream waters far exceeded $\mathrm{CO}_{2}$ degassing from groundwater in the carbonate catchment, with possible $\mathrm{CO}_{2}$ uptake by the stream. The results of this study emphasize the importance of $\mathrm{CO}_{2}$ export associated with groundwater discharge at the headwater regions and the evaluation of its variability with the catchment lithology for a more comprehensive carbon budget of river systems.

Acknowledgements. The authors thank Seong Hoon Chung, Sang Yeol Lee, Woo Ho Myung, Ji Seung Park, Ahn Na Jo, Hee Jin Ahn, Soo Jin Ham, Byeong Il Ahn, and Nam Yeong Jo for their help with the fieldwork, Jong-Sik Ryu for his scientific comments, and the reviewers who improved the manuscript. This work was supported by an IPET (Korea Institute of Planning and Evaluation for Technology of Food, Agriculture, Forestry and Fisheries) grant, by a National Agenda Project, and in part by the Sustainable Water Resource Research Center of the 21st Century Frontier Research Program (Code 1-8-3).

Edited by: A. D. Reeves

\section{References}

Amiotte-Suchet, P., Aubert, D., Probst, J. L., Gauthier-Lafaye, F., Probst, A., Andreux, F., and Viville, D.: $\delta^{13} \mathrm{C}$ pattern of dissolved inorganic carbon in a small granitic catchment: the Strengbach case study (Vosges Mountains, France), Chem. Geol., 159, 129-145, 1999.

Atekwana, E. A. and Krishnamurthy, R. V.: Seasonal variations of dissolved inorganic carbon and $\delta^{13} \mathrm{C}$ of surface waters: application of a modified gas evolution technique, J. Hydrol., 205, 265-278, 1998.

Barth, J. A. C. and Veizer, J.: Carbon cycle in St. Lawrence aquatic ecosystems at Cornwall (Ontario), Canada: seasonal and spatial variations, Chem. Geol., 159, 107-128, 1999.

Borges, A. V., Vanderborght, J.-P., Schiettecatte, L.-S., Gazeau, F., Ferrón-Smith, S., Delille, B., and Frankignoulle, M.: Variability of the gas transfer velocity of $\mathrm{CO}_{2}$ in a macrotidal estuary (the Scheldt), Estuaries, 27, 593-603, doi:10.1007/BF02907647, 2004.

Brunet, F., Gaiero, D., Probst, J. L., Depetris, P. J., Gauthier Lafaye, F., and Stille, P.: $\delta^{13} \mathrm{C}$ tracing of dissolved inorganic carbon sources in Patagonian rivers (Argentina), Hydrol. Process., 19, 3321-3344, 2005.

Brunet, F., Dubois, K., Veizer, J., Nkoue Ndondo, G. R., Nadam Ngoupayou, J. R., Boeglin, J. L., and Probst, J. L.: Terrestrial and fluvial carbon fluxes in a tropical watershed: Nyong Basin, Cameroon, Chem. Geol., 265, 563-572, 2009.

Clark, I. D. and Fritz, P.: Environmental Isotope Hydrogeology, Lewis Publishers, New York, 1997.
Cole, J., Prairie, Y. T., Caraco, N. F., McDowell, W. H., Tranvik, L. J., Striegl, R. G., Duarte, C. M., Kortelainen, P., Downing, J. A., Middelburg, J. J., and Melack, J.: Plumbing the global carbon cycle: Integrating inland waters into the terrestrial carbon budget, Ecosystems, 10, 171-184, doi:10.1007/s10021-006-9013-8, 2007.

Doctor, D. H., Kendall, C., Sebestyen, S. D., Shanley, J. B., Ohte, N., and Boyer, E. W.: Carbon isotope fractionation of dissolved inorganic carbon (DIC) due to outgassing of carbon dioxide from a headwater stream, Hydrol. Process., 22, 2410-2423, doi:10.1002/hyp.6833, 2008.

Dubois, K. D., Lee, D., and Veizer, J.: Isotopic constraints on alkalinity, dissolved organic carbon, and atmospheric carbon dioxide fluxes in the Mississippi River, J. Geophys. Res., 115, G02018, doi:10.1029/2009JG001102, 2010.

Finlay, J. C.: Controls of streamwater dissolved inorganic carbon dynamics in a forested watershed, Biogeochemistry, 62, 231252, 2003.

Friedlingstein, P., Dufresne, J.-L., Cox, P. M., and Rayner, P.: How positive is the feedback between climate change and the carbon cycle?, Tellus B, 55, 692-700, 2003.

Genereux, D. P. and Hooper, R. P.: Oxygen and hydrogen isotopes in rainfall-runoff studies, in: Isotope Tracers in Catchment Hydrology, edited by: Kendall, C. and McDonell, J. J., Elsevier, Amsterdam, 319-346, 1998.

Govindasamy, B., Thompson, S., Mirin, A., Wickett, M., Caldeira, K., and Delire, C.: Increase of carbon cycle feedback with climate sensitivity: results from a coupled climate and carbon cycle model, Tellus B, 57, 153-163, 2005.

Hill, T. and Neal, C.: Spatial and temporal variation in $\mathrm{pH}$, alkalinity and conductivity in surface runoff and groundwater for the Upper River Severn catchment, Hydrol. Earth Syst. Sci., 1, 697715, doi:10.5194/hess-1-697-1997, 1997.

Hope, D., Palmer, S. M., Billett, M. F., and Dawson, J. J. C.: Variations in dissolved $\mathrm{CO}_{2}$ and $\mathrm{CH}_{4}$ in a first-order stream and catchment: an investigation of soil-stream linkages, Hydrol. Process., 18, 3255-3275, 2004.

Johnson, M. S., Lehmann, J., Riha, S. J., Krusche, A. V., Richey, J. E., Ometto, J. P. H. B., and Couto, E. G.: $\mathrm{CO}_{2}$ efflux from Amazonian headwater streams represents a significant fate for deep soil respiration, Geophys. Res. Lett., 35, L17401, doi:10.1029/2008GL034619, 2008.

Kim, J. C., Koh, H. J., Lee, S. R., Lee, C. B., Choi, S. J., and Park, K. H.: Geologic map and explanatory note of the GangreungSokcho sheet, Korea Institute of Geoscience and Mineral Resources, Daejeon, Korea, 2001.

Langmuir, D.: Aqueous Environmental Chemistry, Prentice-Hall, 1997.

Ludwig, W., Amiotte-Suchert, P., Munhoven, G., and Probst, J. L.: Atmospheric $\mathrm{CO}_{2}$ consumption by continental erosion: presentday control and implications for the last glacial maximum, Global Planet. Change, 16-17, 107-120, 1997.

Meybeck, M.: Global chemical weathering of surficial rocks estimated from river dissolved loads, Am. J. Sci., 287, 401-428, 1987.

Öquist, M. G., Wallin, M., Seibert, J., Bishop, K., and Laudon, H.: Dissolved inorganic carbon export across the soil/stream interface and its fate in a boreal headwater stream, Environ. Sci. Technol., 43, 7364-7369, 2009. 
Parkhurst, D. L. and Appelo, C. A. J.: User's guide to PHREEQC (version 2) - a computer program for speciation, batchreaction, one-dimensional transport, and inverse geochemical calculations, US Geological Survey Water-Resources Investigations Report, USGS, 99-4259, 312 pp., 1999.

Richey, J. E., Melack, J. M., Aufdenkampe, A. K., Ballester, V. M., and Hess, L. L.: Outgassing from Amazonian rivers and wetlands as a large tropical source of atmospheric $\mathrm{CO}_{2}$, Nature, 416, 617620, 2002.

Rounds, S. A. and Wilde, F. D.: Field Measurements: US Geological Survey Techniques of Water-Resources investigations, Book 9, Chapt. A6, Sect. 6.2, USGS, 2001.

Spence, J. and Telmer, K., The role of sulfur in chemical weathering and atmospheric $\mathrm{CO}_{2}$ fluxes: Evidence from major ions, $\delta^{13} \mathrm{C}_{\text {DIC }}$, and $\delta^{34} \mathrm{~S}_{\mathrm{SO}_{4}}$ in rivers of the Canadian Cordillera, Geochim. Cosmochim. Acta, 69, 5441-5458, 2005.

Tan, F. C. and Edmond, J. M.: Carbon isotope geochemistry of the Orinoco Basin, Estuar. Coast. Shelf S., 36, 541-547, 1993.

Taylor, C. B. and Fox, V. J.: An isotopic study of dissolved inorganic carbon in the catchment of the Waimakariri River and deep ground water of the North Canterbury Plains, New Zealand, J. Hydrol., 186, 161-190, 1996.
Waldron, S., Scott, E. M., and Soulsby, C.: Stable isotope analysis reveals lower-order river dissolved inorganic carbon pools are highly dynamic, Environ. Sci. Technol., 41, 6156-6162, 2007.

Wanninkhof, R.: Relationship between wind speed and gas exchange over the ocean, J. Geophys. Res., 97, 7373-7382, doi:10.1029/92JC00188, 1992.

Yang, C., Telmer, K., and Veizer, J.: Chemical dynamics of the "St. Lawrence" riverine system: $\delta \mathrm{D}_{\mathrm{H}_{2} \mathrm{O}}, \delta{ }^{18} \mathrm{O}_{\mathrm{H}_{2} \mathrm{O}}, \delta^{13} \mathrm{C}_{\mathrm{DIC}}$, $\delta^{34} \mathrm{~S}_{\text {sulfate, }}$ and dissolved ${ }^{87} \mathrm{Sr} /{ }^{86} \mathrm{Sr}$, Geochim. Cosmochim. Acta, 60, 851-866, 1996.

Yao, G., Gao, Q., Wang, Z., Huang, X., He, T., Zhang, Y., Jiao, S., and Ding, J.: Dynamics of $\mathrm{CO}_{2}$ partial pressure and $\mathrm{CO}_{2}$ outgassing in the lower reaches of the Xijiang River, a subtropical monsoon river in China, Sci. Total Environ., 376, 255-266, 2007.

Zhang, J., Quay, O. D., and Wilbur, D. O.: Carbon isotope fractionation during gas-water exchange and dissolution of $\mathrm{CO}_{2}$, Geochim. Cosmochim. Acta, 59, 107-114, 1995. 